\title{
PENGARUH AGREGAT GABUNGAN TERHADAP HASIL MARSHALL UNTUK HRS-WC DAN HRS-BASE
}

\author{
Rifanie Gazalie ${ }^{1}$, Muhammad Firdaus ${ }^{2}$, Riska Hawinuti ${ }^{3}$ \\ 1,2,3 Jurusan Teknik Sipil, Politeknik Negeri Banjarmasin \\ email: ${ }^{1}$ rifanieg@gmail.com (corresponding author), ${ }^{2}$ dauspoli@gmail.com, ${ }^{3}$ riska_hawinuti@yahoo.co.id
}

\begin{abstract}
Abstrak
Penyebab kegagalan dan kerusakan pada perkerasan jalan adalah karena penggunaan aspal dengan nilai penetrasi tinggi dengan kadar aspal rendah dan pelaksanaan campuran yang belum sesuai dengan persyaratan yang ada, sehingga mengurangi umur rencana jalan. Kegagalan lapisan perkerasan aspal yang paling umum adalah deformasi permanen akibat stabilitas yang kurang dan retak akibat kelelahan. Pertimbangan utama dalam menentukan kualitas campuran aspal salah satunya adalah kekuatan agregat agar bertahan lama sesuai dengan perencanaan. Permasalahan yang dibahas pada penelitian ini adalah bagaimana pengaruh agregat gabungan terhadap kadar aspal optimum dan nilai stabilitas campuran aspal. Sampel penelitian adalah aspal penetrasi 60/70, agregat kasar Awang Bangkal dan Katunun Pelaihari, agregat halus pasir Barito, filler debu batu pecah Awang Bangkal dan Semen Tiga Roda, sebanyak 48 sampel dengan kadar aspal 5-7\%. Parameter campuran seperti stabilitas, kelelehan (flow), rongga udara dalam campuran (VIM), rongga dalam agregat (VMA), rongga terisi aspal (VFA), Marshall Quotient (MQ), dan rongga dalam kepadatan mutlak (VIM refusal untuk AC-WC) ditentukan dari analisis Marshall. Hasil dicapai adalah adanya pengurangan pemakaian kadar aspal optimum sebesar 0,5\% untuk agregat gabungan Awang Bangkal dan Katunun Pelaihari pada campuran Lataston Lapis Aus (HRS-WC) dan pengurangan pemakaian kadar aspal optimum sebesar 0,2\% pada campuran Lataston Lapis Pondasi (HRSBase) pada spesifikasi yang minimal sebesar $800 \mathrm{~kg}$.
\end{abstract}

Kata Kunci : Agregat, Aspal, Lataston Lapis Aus (HRS-WC), Lataston Lapis Pondasi (HRS-Base)

Abstract
The cause of the failure and damage to the roughness of the road is because the use of asphalt with high penetration value concurent with low levels mixture asphalt and the implementation of which has not been in compliance with the existing requirements, thus reduce the age of the road plan. The most commont asphalt roughness layer failure is permanent deformation AS a result of less stability and crack due to fatigue. One of the main consideration in determe the quality of asphalt mixture is the strength of the aggregate in order to endure in compliance with road planning. The issues discussed in this research is how the combined aggregate influence towards optimum levels of asphalt and asphalt mixture stability value. The research sample is asphalt penetration 60/70, coarse aggregate Awang Bangkal and Katunun-Banjarbaru Pelaihari, fine aggregate is Barito sand, filler Awang Bangkal rock burst and Tiga Roda Cement, witch total of 48 samples with levels 5-7\% asphalt. Parameters of mix are stability, flow of air cavities, Voids in Mix (VIM), Void in Mineral aggeggate (VMA), Void Filled with Asphalt (VFA), Marshall Quotient (MQ), and VIM refusal to AC-WC determined from analysis of Marshall. The result achieved is the reduction in consumption levels of optimum asphalt of $0.5 \%$ for combined aggregate Awang Bangkal and Katunun Lataston mixed HRS-WC and a reduction in consumption levels of optimum asphalt of $0.2 \%$ on the mix HRS-Base on the minimum spesification $800 \mathrm{~kg}$.

Keywords: Aggregate, asphalt, Hot Rolled Sheet Wearing Course (HRS-WC), Hot Rolled Sheet Base (HRS-Base)

\section{PENDAHULUAN}

Kegagalan dan kerusakan pada perkerasan jalan karena penggunaan aspal dengan nilai penetrasi tinggi serta kadar aspal rendah atau tinggi ternyata berbanding lurus dengan cara pelaksanaan campuran yang belum sesuai dengan persyaratan yang ada. Hal inilah yang menjadi salah satu faktor penyebab berkurangnya umur rencana dari suatu jalan. 
Kegagalan lapisan perkerasan aspal yang paling umum adalah deformasi permanen akibat stabilitas yang kurang dan retak akibat kelelahan. Pertimbangan utama dalam menentukan kualitas campuran aspal salah satunya adalah kekuatan agregat agar bertahan lama sesuai dengan perencanaan.

Sebagian besar jalan di Indonesia masih menggunakan lapisan aspal berupa Lapis Tipis Aspal Beton (Lataston) yang selanjutnya disebut HRS. Hal inilah yang mendasari penelitian "Pengaruh Agregat Gabungan Terhadap Hasil Marshall untuk HRS-WC dan HRS-Base”. Studi ini akan melakukan percobaan laboratorium dengan menggunakan 2 (dua) bahan yang berbeda, yaitu Lataston Lapis Aus (HRSWC) dan Lataston Lapis Pondasi (HRS-Base), sesuai dengan spesifikasi teknis campuran aspal yang telah ditentukan untuk diuji dan hasilnya dianalisis. Dengan adanya studi ini, dapat diketahui besarnya pengaruh agregat gabungan terhadap hasil campuran aspal sehingga jalan tidak mengalami kerusakan lagi sebelum akhir umur rencana.

Tujuan penelitian ini adalah mengetahui besarnya pengaruh agregat gabungan terhadap kadar aspal optimum dan nilai stabilitas untuk Lataston Lapis Aus (HRS-WC) dan Lataston Lapis Pondasi (HRS-Base). Sehingga dapat memberikan manfaat dalam hal pengoptimalan bahan material campuran aspal pada pemakaian agregat campuran aspal khususnya agregat kasar. Agregat kasar yang nilai abrasinya tidak memenuhi persyaratan, masih dapat dipergunakan dengan mencampurnya menjadi agregat gabungan dengan agregat kasar yang lain yang memenuhi persyaratan. Sehingga tidak ada agregat kasar yang tidak bisa dipakai dalam proses pelaksanaan campuran aspal.

\section{A. Lataston}

Lataston (Lapis Tipis Aspal Beton), dikenal dengan nama Hot Roll Sheet (HRS) merupakan lapis penutup yang terdiri dari campuran antara agregat bergradasi timpang, bahan pengisi (filler), dan aspal keras dengan perbandingan tertentu, yang dicampur dan dipadatkan pada suhu minimal sesuai yang disyaratkan. Tebal padat minimal $3 \mathrm{~cm}$, bersifat kedap air, sangat kenyal, awet, dan dianggap tidak memiliki nilai struktural.

Lataston terdiri dari dua macam campuran yaitu HRS-WC untuk Lapis Aus/Permukaan dan HRS-Base untuk Lapis Pondasi, dengan ukuran agregat maksimum masing-masing campuran adalah $19 \mathrm{~mm}$. HRS-Base mempunyai proporsi fraksi agregat kasar lebih besar daripada HRS-WC.

\section{B. Agregat}

Agregat merupakan komponen utama dari lapisan perkerasan dengan perbandingan 90\%-95\% agregat berdasarkan persentasi berat atau 75\%-85\% agregat berdasarkan volume. Agregat dengan kualitas yang baik dibutuhkan untuk lapisan permukaan yang langsung memikul beban lalu lintas dan menyebarkan ke lapisan di bawahnya.

Syarat utama agregat yang harus diperhatikan dalam campuran Lataston, yaitu:

1. Penyerapan air oleh agregat maksimum $3 \%$
2. Berat jenis (Spesific Gravity) agregat kasar dan halus tidak boleh berbeda dari 0,2 .

Agregat terdiri dari dua, yaitu agregat kasar dan agregat halus. Agregat kasar adalah berupa batu pecah mesin atau kerikil pecah mesin yang tertahan ayakan No.4 (4,75 mm) yang dilakukan secara basah dan harus bersih, keras, awet dan bebas dari lempung atau bahan yang tidak dikehendaki lainnya, sedangkan agregat halus adalah material yang terdiri dari pasir atau hasil pengayakan batu pecah dan terdiri bahan yang lolos ayakan No.4 (4,75 mm), bersih, keras, bebas dari lempung atau bahan yang tidak dikehendaki lainnya.

\section{Bahan Pengisi (Filler) untuk Campuran Aspal}

Bahan pengisi yang ditambahkan (filler added) terdiri atas debu batu kapur atau debu kapur padam yang sesuai, semen atau mineral yang berasal dari Asbuton, harus kering dan bebas dari gumpalan-gumpalan dan bila diuji harus mengandung bahan yang lolos ayakan No.200 (75 micron) tidak kurang dari $75 \%$ terhadap beratnya.

\section{Gradasi Agregat Gabungan}

Gradasi agregat gabungan untuk campuran aspal, ditunjukkan dalam persen terhadap berat agregat dan bahan pengisi, harus memenuhi batas-batas yang diberikan pada Tabel I berikut.

Tabel I

Amplop Gradasi Agregat Gabungan untuk Campuran Aspal

\begin{tabular}{|c|c|c|c|}
\hline \multicolumn{2}{|c|}{ Ukuran Saringan } & \multicolumn{2}{c|}{ Persen Lolos (\%) } \\
\cline { 3 - 4 } & & Lataston (HRS) gradasi semi senjang \\
\hline Inchi & mm & HRS-WC & HRS-Base \\
\hline $3 / 4$ & 19 & 100 & 100 \\
$1 / 2$ & 12,5 & $87-100$ & $90-100$ \\
$3 / 8$ & 9,5 & $55-88$ & $55-70$ \\
No. 8 & 2,36 & $50-62$ & $32-44$ \\
No.30 & 0,600 & $20-45$ & $15-35$ \\
No. 50 & 0,300 & $15-35$ & $5-35$ \\
No. 200 & 0,075 & $6-10$ & $4-8$ \\
\hline
\end{tabular}

Sumber: Spesifikasi Umum Bina Marga Revisi 3 (2010)

\section{E. Aspal}

Aspal dapat didefinisikan sebagai material yang berwarna hitam atau coklat tua dan merupakan material yang bersifat termoplastis yaitu mencair jika dipanaskan dan kembali menjadi padat jika didinginkan kembali. Fungsi aspal bagi konstruksi jalan adalah:

1. Menutup permukaan jalan sehingga kedap air

2. Sebagai bahan pengikat antara agregat atau lapisan-lapisan konstruksi jalan

3. Menambah stabilitas atau memberikan semacam bantalan antara batuan

Sesuai dengan fungsinya, aspal yang digunakan selain harus memenuhi spesifikasi dan persyaratan pemeriksaan laboratorium seperti terlihat pada Tabel II, untuk aspal penetrasi 60/70. Dalam pelaksanaannya harus memenuhi persyaratan sebagai berikut:

1. Aspal harus melapisi batuan dengan rapat.

2. Aspal yang digunakan tidak menjadi rapuh. 
3. Aspal yang digunakan mempunyai sifat melekat yang baik terhadap batuan yang dilapisi.

4. Aspal yang melapisi batuan tidak peka terhadap perubahan suhu.

5. Aspal harus memberikan lapisan yang elastis pada batuan.

Tabel II

Ketentuan-ketentuan untuk Aspal Keras

\begin{tabular}{|l|c|}
\hline \multicolumn{1}{|c|}{ Jenis Pengujian } & Aspal Keras Pen. 60/70 \\
\hline Penetrasi aspal $(0.1 \mathrm{~mm})$ & $60-70$ \\
Titik lembek $\left({ }^{\circ} \mathrm{C}\right)$ & $\geq 48$ \\
Titik nyala $\left({ }^{\circ} \mathrm{C}\right)$ & $\geq 232$ \\
Daktilitas $25^{\circ} \mathrm{C}(\mathrm{cm})$ & $\geq 100$ \\
Berat jenis $\left(\mathrm{gr} / \mathrm{cm}^{3}\right)$ & $\geq 1,0$ \\
\hline
\end{tabular}

Sumber: Spesifikasi Umum Bina Marga Revisi 3 (2010)

\section{F. Ketentuan Sifat-Sifat Campuran}

Campuran aspal terdiri dari agregat dan aspal. Filler yang ditambahkan boleh digunakan bilamana diperlukan untuk menjamin sifat-sifat campuran memenuhi ketentuan yang disyaratkan pada Tabel III berikut.

Tabel III

Ketentuan Sifat-Sifat Campuran Lataston

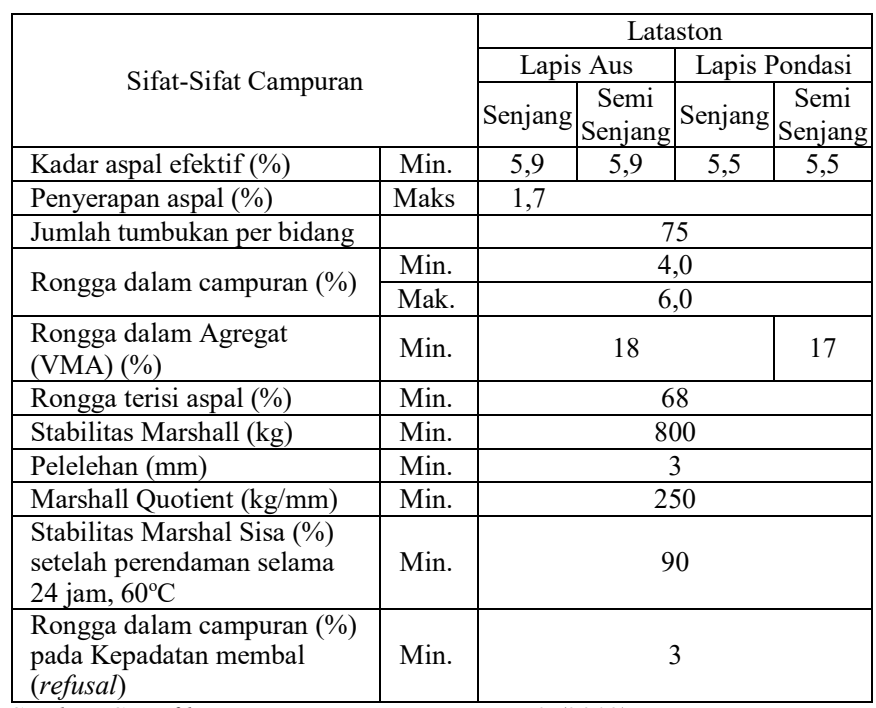

Sumber: Spesifikasi Umum Bina Marga Revisi 3 (2010)

\section{G. Pencampuran Aspal dan Agregat}

Metode pencampuran yang digunakan dalam penelitian ini adalah Metode Marshall yaitu suatu metode percobaan laboratorium untuk menentukan jumlah kadar aspal optimum sehingga diperoleh suatu campuran yang sesuai antara agregat dan aspal yang digunakan. Pemeriksaan dengan metode Marshall ini bertujuan untuk mendapat nilai kekuatan (stability) terhadap kelelehan plastis (flow).

Dari pengujian benda uji dengan alat Marshall akan diperoleh data-data sebagai berikut:

1. Stabilitas, yang dinyatakan dalam bilangan bulat yang didapat dari pembacaan dial arloji pada alat Marshall.
2. Kelelehan plastis (flow), dinyatakan dalam $\mathrm{mm}$ atau 0,01 inchi yang diperoleh dari hasil pembacaan dial arloji pada alat Marshall.

3. Berat Jenis, yaitu perbandingan antara berat kering benda uji dengan isi benda uji, yang didapatkan dengan rumus:

$$
D=\frac{E}{H}
$$

Dimana: $\mathrm{D}=$ berat jenis atau density $\left(\mathrm{gr} / \mathrm{cm}^{3}\right)$

$$
\mathrm{E}=\text { berat kering benda uji (gr) }
$$$$
\mathrm{H}=\text { Isi benda uji }\left(\mathrm{cm}^{3}\right)
$$

4. Rongga dalam campuran, dinyatakan dalam bilangan desimal satu angka dibelakang koma yang didapat dari persamaan berikut:

$$
V I M=\frac{100 \times(\mathrm{Gmm}-\mathrm{D})}{\mathrm{Gmm}}
$$

Dimana: VIM = rongga udara dalam campuran

$\mathrm{Gmm}=$ berat jenis maksimum campuran

5. Hasil bagi Marshall (Marshall Quotient), merupakan hasil bagi antara stabilitas dan flow yang didapatkan dengan persamaaan:

$$
M Q=\frac{M}{102 N}
$$

Dimana: $\mathrm{MQ}=$ Marshall Quotient $(\mathrm{kN} / \mathrm{mm})$

$\mathrm{M}=$ Stabilitas yang disesuaikan/ terkoreksi $(\mathrm{kg})$

$\mathrm{N}=$ Nilai kelelehan plastis $(\mathrm{mm})$

Sebelum mengadakan pencampuran aspal dan agregat untuk membuat benda uji, tentukan dahulu persentasi agregat dan aspal yang akan digunakan. Untuk persentasi aspal bisa bervariasi dari $4 \%$ sampai dengan $8 \%$, sehingga nantinya didapatkan kadar aspal optimum. Sedangkan untuk penggabungan gradasi dari semua agregat dengan menggunakan metode resep (spek ideal).

\section{H. Marshall Test}

Pemeriksaan terhadap campuran dilakukan dengan Marshall Test yang bertujuan untuk menentukan ketahanan (stability) dan kelelehan (flow) dari campuran aspal dan agregat. Prosedur percobaan Marshall Test yang dilakukan mengikuti SNI M-01-2003.

Stabilitas benda uji adalah kemampuan maksimum benda uji yang dihasilkan pada suhu $60^{\circ} \mathrm{C}$ dan diuji dengan alat tertentu. Nilai flow adalah pergerakan total atau regangan yang terjadi dalam benda uji antara kondisi tanpa beban dan beban maksimum selama pengujian stabilitas (Aspalt Institute, 1993).

Perbandingan stabilitas terhadap flow dinamakan Marshall Quotient (Shell, 1990).

\section{Uji Statistik}

Untuk mendapatkan hasil yang valid dan reliabel maka perlu ada pengujian hipotesis statistik sebagai alat untuk melihat taraf signifikannya. Valid menunjukkan derajat ketepatan yaitu ketepatan antara data yang sesungguhnya dengan hasil perhitungan dan reliabel menunjukkan derajat 
konsistensi dari suatu hasil dari formula terhadap data yang sesungguhnya.

Pengujian dilakukan terhadap beberapa model regresi, antara lain:

1. Linier $\quad \mathrm{Y}=\mathrm{a}+\mathrm{bx}$

2. Logarithmic $\mathrm{Y}=\mathrm{a}+\mathrm{b} \operatorname{Lnx}$

3. Polynomial $\mathrm{Y}=\mathrm{a}+\mathrm{bx}+\mathrm{cx}^{2}$

Dari hasil pengujian model regresi tersebut didapatkan persamaan-persamaan dan nilai R kuadrat (koefisien korelasi determinasi), dimana nilai $\mathrm{R}$ kuadrat terbesar adalah merupakan model yang terbaik dan dipilih.

\section{METODE PENELITIAN}

\section{A. Percobaan Laboratorium dan Perhitungan}

Percobaan laboratorium adalah dengan melakukan percobaan langsung terhadap material/ bahan yang digunakan dan uji kekuatan terhadap campuran yang dipakai.

Adapun percobaan-percobaan yang dilakukan antara lain:

1) Terhadap Aspal: Pemeriksaan penetrasi dengan mengikuti SNI 06-2456-2011, pemeriksaan titik lembek dengan mengikuti SNI 06-2434-2011 dan pemeriksaan berat jenis aspal, yang dimaksudkan untuk mengetahui berat jenis aspal keras dengan mengikuti SNI 06-2441-2011.

2) Terhadap Agregat: Pemeriksaan analisa saringan agregat dengan mengikuti SNI 03-1968-1990, pemeriksaan kekerasan/ keausan dengan mengikuti SNI 03-2417-2008, pemeriksaan kelekatan agregat terhadap aspal dengan mengikuti SNI 03-2439-2011, pemeriksaan berat jenis dan penyerapan agregat kasar dengan mengikuti SNI 1969-2008, pemeriksaan berat jenis dan penyerapan agregat halus dengan mengikuti SNI 1970-2008.

3) Pemeriksaan Terhadap Campuran dengan Marshall Test: Bertujuan untuk menentukan ketahanan (stabilitas) dan kelelehan (flow) dari campuran aspal dan agregat. Prosedur percobaan Marshall test mengikuti SNI M-01-2003.

4) Material yang Digunakan: Material yang digunakan dalam penelitian ini adalah aspal/ bitumen dengan penetrasi 60/70, agregat kasar berupa batu pecah Awang Bangkal dan Katunun Pelaihari, agregat halus yang digunakan adalah pasir Barito, filler yang digunakan berupa filler dari abu batu dan Semen Tiga Roda.

5) Jumlah Benda Uji: Benda uji dibuat dengan mencampurkan aspal, agregat kasar, agregat halus dan filler.

1. Untuk contoh campuran aspal HRS-WC dan HRS-Base menggunakan agregat kasar Awang Bangkal masingmasing sebanyak 12 (dua belas) buah dalam menentukan kadar aspal optimum.

2. Campuran aspal HRS-WC dan HRS-Base menggunakan agregat kasar gabungan Awang Bangkal dan Katunun Pelaihari, masing-masing sebanyak 12 (dua belas) buah dalam menentukan kadar aspal optimum.
3. Untuk agregat kasar gabungan Awang Bangkal dan Katunun Pelaihari dipakai agregat Awang Bangkal yang lolos nomor saringan $3 / 4$ " dan agregat Katunun Pelaihari tertahan nomor saringan $3 / 8$ ".

4. Total sampel (bricket) yang dibuat adalah 48 (empat puluh delapan) sampel.

\section{Bagan Alir}

Bagan Alir dapat dilihat pada Gambar 1 berikut.

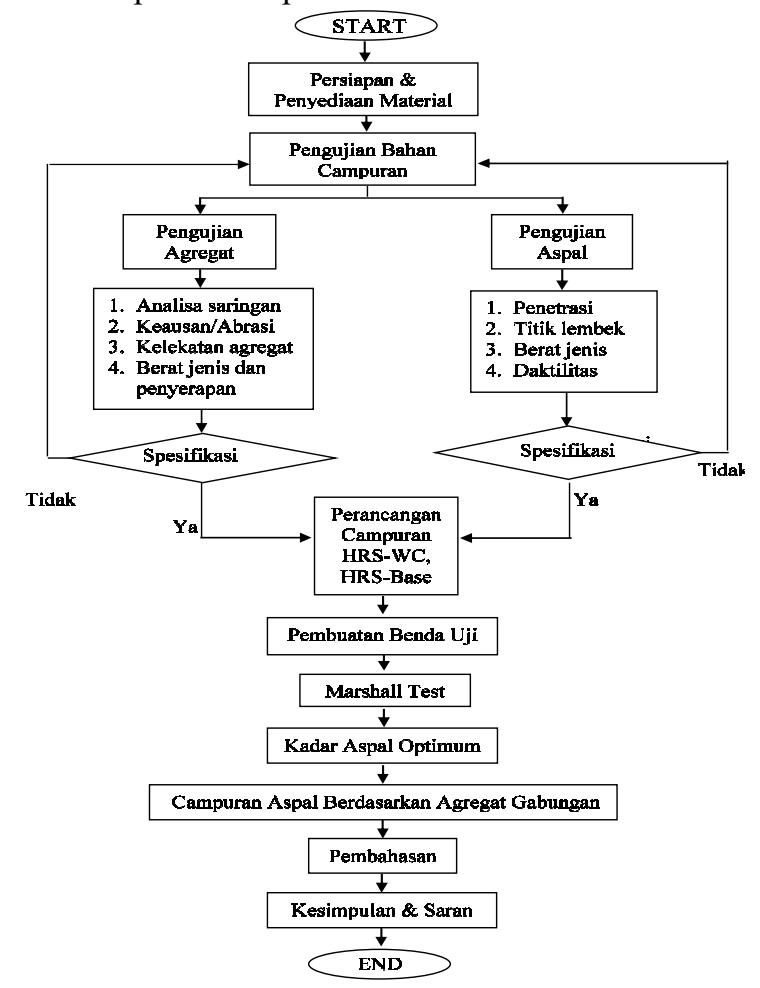

Gambar 1. Bagan Alir Penelitian

\section{HASIL DAN PEMBAHASAN}

Data yang diperoleh merupakan data yang didapatkan dari hasil percobaan dan pemeriksaan semua material yang digunakan dalam campuran Lataston Lapis Aus (HRS-WC) dan Lataston Lapis Pondasi (HRS-Base).

\section{A) Pengujian Agregat Kasar}

Agregat yang digunakan dalam penelitian ini berupa batu pecah yang berasal dari Awang Bangkal, dengan ukuran maksimal lolos saringan No.3/4" dan tertahan pada saringan No.4. Untuk lebih lengkapnya data hasil pengujian agregat kasar dapat dilihat pada Tabel IV dan Tabel V berikut.

Tabel IV

Hasil Pengujian Agregat Kasar Awang Bangkal

\begin{tabular}{|l|c|c|c|c|}
\hline \multirow{2}{*}{ Jenis pengujian } & \multicolumn{2}{|c|}{ Hasil } & \multirow{2}{*}{ Satuan } & Syarat \\
\cline { 2 - 5 } & 1 & 2 & gr/cc & - \\
\hline Berat jenis (Bulk) & 2,426 & 2,384 & gr/cc & - \\
\hline $\begin{array}{l}\text { Berat jenis permukaan } \\
\text { jenuh (SSD) }\end{array}$ & 2,463 & 2,419 & . \\
\hline
\end{tabular}




\begin{tabular}{|l|c|c|c|c|}
\hline $\begin{array}{l}\text { Berat jenis semu } \\
\text { (Apparent) }\end{array}$ & 2,519 & - & $\mathrm{gr} / \mathrm{cc}$ & Min.2,5 \\
\hline Penyerapan (Absorbtion) & 1,518 & 1,462 & $\%$ & $<3 \%$ \\
\hline Keausan (Abration) & \multicolumn{2}{|c|}{44,13} & $\%$ & $<40 \%$ \\
\hline Kelekatan terhadap aspal & $>95$ & $\%$ & $>95 \%$ \\
\hline Analisa saringan & - & - & - \\
\hline
\end{tabular}

Tabel V

Hasil Pengujian Agregat Kasar Katunun Pelaihari

\begin{tabular}{|l|c|c|c|c|}
\hline \multirow{2}{*}{ Jenis pengujian } & \multicolumn{2}{|c|}{ Hasil } & \multirow{2}{*}{ Satuan } & \multirow{2}{*}{ Syarat } \\
\cline { 2 - 5 } & 1 & 2 & $\mathrm{gr} / \mathrm{cc}$ & - \\
\hline Berat jenis (Bulk) & - & - & $\mathrm{gr} / \mathrm{cc}$ & - \\
\hline $\begin{array}{l}\text { Berat jenis permukaan } \\
\text { jenuh (SSD) }\end{array}$ & - & - & $\mathrm{gr} / \mathrm{cc}$ & $\mathrm{Min} .2,5$ \\
\hline $\begin{array}{l}\text { Berat jenis semu } \\
\text { (Apparent) }\end{array}$ & - & - & $\%$ & $<3 \%$ \\
\hline Penyerapan (Absorbtion) & - & - & $\%$ & $<40 \%$ \\
\hline Keausan (Abration) & \multicolumn{2}{|c|}{24,12} & $\%$ & $>95 \%$ \\
\hline Kelekatan terhadap aspal & \multicolumn{2}{|c|}{-} & - & - \\
\hline Analisa saringan & \multicolumn{2}{|c|}{} \\
\hline
\end{tabular}

Dokumentasi pelaksanaan pengujian agregat kasar dapat dilihat pada Gambar 2 dan Gambar 3 berikut.

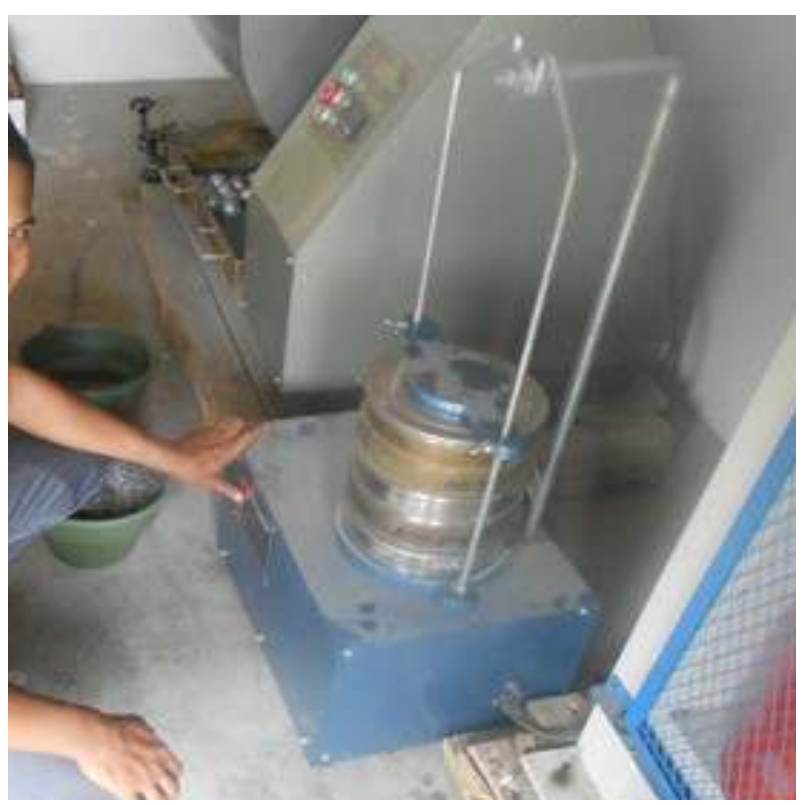

Gambar 2. Pelaksanaan Analisa Saringan

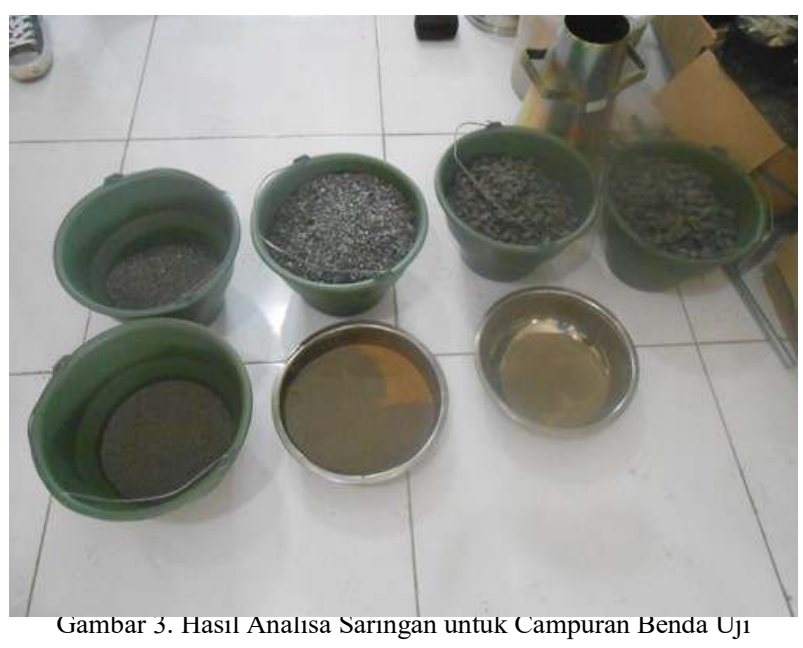

\section{B) Pengujian Agregat Halus}

Agregat halus digunakan dalam penelitian ini adalah pasir yang berasal dari Barito, dengan ukuran maksimal 4,75 mm atau lolos saringan No. 4 dan tertahan pada saringan No. 200. Untuk hasil dari pengujian agregat halus dapat dilihat pada Tabel VI berikut.

Tabel VI

Hasil pengujian Agregat Halus Pasir Barito

\begin{tabular}{|c|c|c|c|c|}
\hline \multirow{2}{*}{ Jenis pengujian } & \multicolumn{2}{|c|}{ Hasil } & \multirow{2}{*}{ Satuan } & \multirow{2}{*}{ Syara } \\
\hline & 1 & 2 & & \\
\hline Berat jenis (Bulk) & 2,482 & 2,468 & $\mathrm{gr} / \mathrm{cc}$ & - \\
\hline $\begin{array}{l}\text { Berat jenis permukaan } \\
\text { jenuh (SSD) }\end{array}$ & 2,494 & 2,490 & $\mathrm{gr} / \mathrm{cc}$ & - \\
\hline $\begin{array}{l}\text { Berat jenis semu } \\
\text { (Apparent) }\end{array}$ & 2,511 & 2,524 & $\mathrm{gr} / \mathrm{cc}$ & Min.2,5 \\
\hline Penyerapan (Absorbtion) & 0,462 & 0,908 & $\%$ & $<3 \%$ \\
\hline Analisa saringan & - & & - & - \\
\hline
\end{tabular}

\section{C) Pengujian Filler}

Filler (bahan pengisi) yang digunakan dalam penelitian ini adalah debu batu pecah Awang Bangkal dan Semen Tiga Roda, dengan ukuran maksimum $0,075 \mathrm{~mm}$ atau lolos saringan No. 200. Bahan yang menjadi filler harus memenuhi persyaratan yaitu harus kering dan bebas dari gumpalangumpalan dan 75\% dari beratnya harus lolos saringan No.200. Hasil pengujian filler dapat dilihat pada Tabel VII berikut.

Tabel VII

Hasil Pengujian Filler Abu Batu Awang Bangkal

\begin{tabular}{|c|c|c|c|c|}
\hline \multirow{2}{*}{ Jenis pengujian } & \multicolumn{2}{|c|}{ Hasil } & \multirow{2}{*}{ Satuan } & \multirow{2}{*}{ Syarat } \\
\hline & 1 & 2 & & \\
\hline Berat jenis (Bulk) & 2,580 & 3,039 & $\mathrm{gr} / \mathrm{cc}$ & - \\
\hline $\begin{array}{l}\text { Berat jenis permukaan } \\
\text { jenuh (SSD) }\end{array}$ & 2,611 & 3,069 & $\mathrm{gr} / \mathrm{cc}$ & - \\
\hline $\begin{array}{l}\text { Berat jenis semu } \\
\text { (Apparent) }\end{array}$ & 2,663 & 3,135 & $\mathrm{gr} / \mathrm{cc}$ & Min.2,5 \\
\hline Penyerapan (Absorbtion) & 1,215 & 1,010 & $\%$ & $<3 \%$ \\
\hline Analisa saringan & & & - & - \\
\hline
\end{tabular}




\section{D) Pengujian Aspal Penetrasi 60/70}

Pengujian dilakukan pada kondisi awal untuk mendapatkan sifat-sifat aspal seperti berat jenis, penetrasi, titik lembek dan daktilitas aspal. Hasil dari pemeriksaan aspal dapat dilihat pada Tabel VIII berikut.

Tabel VIII

Hasil Pengujian Aspal Penetrasi 60/70

\begin{tabular}{|l|c|c|c|c|}
\hline \multirow{2}{*}{ Jenis pengujian } & \multicolumn{2}{|c|}{ Hasil } & \multirow{2}{*}{ Satuan } & \multirow{2}{*}{ Syarat } \\
\cline { 2 - 3 } Berat jenis (Bulk) & \multicolumn{2}{|c|}{2} & 2 & \\
\hline Penetrasi aspal & \multicolumn{2}{|c|}{1,06} & gr/cc & $>1,00$ \\
\hline Titik lembek & 62,8 & 67,8 & $\mathrm{~mm}$ & $60-79$ \\
\hline Daktilitas & 48,5 & 49,0 & ${ }^{0} \mathrm{C}$ & $48-58$ \\
\hline
\end{tabular}

\section{E) HRS-WC Agregat Awang Bangkal}

Berikut adalah hasil pengujian Marshall dengan variasi kadar aspal 5\%-7\% untuk HRS-WC (Agregat Awang Bangkal).

Tabel IX

Hasil Pengujian Marshall pada Benda Uji dengan Variasi Kadar Aspal 5-7\% untuk HRS-WC

\begin{tabular}{|c|c|c|c|c|c|c|c|}
\hline $\begin{array}{c}\text { Kadar } \\
\text { aspal } \\
(\%)\end{array}$ & $\begin{array}{c}\text { Stabilitas } \\
(\mathrm{kg})\end{array}$ & $\begin{array}{c}\text { Flow } \\
(\mathrm{mm})\end{array}$ & $\begin{array}{c}\text { Berat } \\
\text { kering } \\
(\mathrm{gr})\end{array}$ & $\begin{array}{c}\text { Berat } \\
\text { dalam } \\
\text { air } \\
(\mathrm{gr})\end{array}$ & $\begin{array}{c}\text { Berat } \\
\text { jenuh } \\
(\mathrm{gr})\end{array}$ & $\begin{array}{c}\text { Tinggi rata- } \\
\text { rata benda } \\
\text { uji } \\
(\mathrm{cm})\end{array}$ & $\begin{array}{c}\text { Koreksi } \\
\text { tinggi }\end{array}$ \\
\hline 5 & 95 & 540 & 1168 & 668,8 & 1176 & 6,30 & 1,09 \\
5 & 115 & 570 & 1165 & 670,6 & 1173 & 6,27 & 1,02 \\
5 & 75 & 600 & 1161 & 660,9 & 1171 & 6,33 & 1,00 \\
5 & 88 & 630 & 1188 & 679,6 & 1193 & 6,40 & 0,96 \\
\hline 6 & 55 & 675 & 1138 & 648,4 & 1144 & 6,20 & 1,04 \\
6 & 63 & 805 & 1197 & 677,8 & 1199 & 6,47 & 0,96 \\
6 & 49 & 1150 & 1224 & 685,3 & 1225 & 6,63 & 0,89 \\
6 & 43 & 1470 & 1210 & 671,1 & 1210 & 6,57 & 0,93 \\
\hline 7 & 91 & 520 & 1164 & 667,8 & 1167 & 6,23 & 1,02 \\
7 & 52 & 1000 & 1195 & 672,5 & 1198 & 6,53 & 0,93 \\
7 & 65 & 720 & 1166 & 644,1 & 1174 & 6,30 & 1,09 \\
7 & 66 & 1010 & 1201 & 675,1 & 1202 & 6,57 & 0,93 \\
\hline
\end{tabular}

(Hasil Pengolahan Data Primer 2016)

Tabel X

Analisa Pengujian Marshall Campuran HRS-WC (Agregat Awang Bangkal)

\begin{tabular}{|c|c|c|c|c|c|c|}
\hline $\begin{array}{c}\text { Kadar } \\
\text { Aspal } \\
(\%)\end{array}$ & $\begin{array}{c}\text { Stabilitas } \\
\text { Terkoreksi } \\
(\mathrm{kg})\end{array}$ & $\begin{array}{c}\text { Flow } \\
(\mathrm{mm})\end{array}$ & $\begin{array}{c}\text { VIM } \\
(\%)\end{array}$ & $\begin{array}{c}\text { VMA } \\
(\%)\end{array}$ & $\begin{array}{c}\text { VFB } \\
(\%)\end{array}$ & $\begin{array}{c}\text { Marshall } \\
\text { Quotient } \\
(\mathrm{kg} / \mathrm{mm})\end{array}$ \\
\hline 5 & 1186,683 & 5,40 & 1,837 & 12,699 & 90,038 & 2,154 \\
5 & 1344,258 & 5,70 & 1,153 & 12,092 & 95,222 & 2,312 \\
5 & 859,500 & 6,00 & 2,980 & 13,716 & 82,394 & 1,404 \\
5 & 968,141 & 6,30 & 1,362 & 12,277 & 93,588 & 1,507 \\
\hline 6 & 655,512 & 6,75 & 0,870 & 13,867 & 99,712 & 0,952 \\
6 & 693,101 & 8,05 & 0,852 & 13,851 & 99,842 & 0,844 \\
6 & 499,771 & 11,50 & 2,090 & 14,928 & 91,485 & 0,426 \\
6 & 458,285 & 14,70 & 3,067 & 15,776 & 85,703 & 3,067 \\
\hline
\end{tabular}




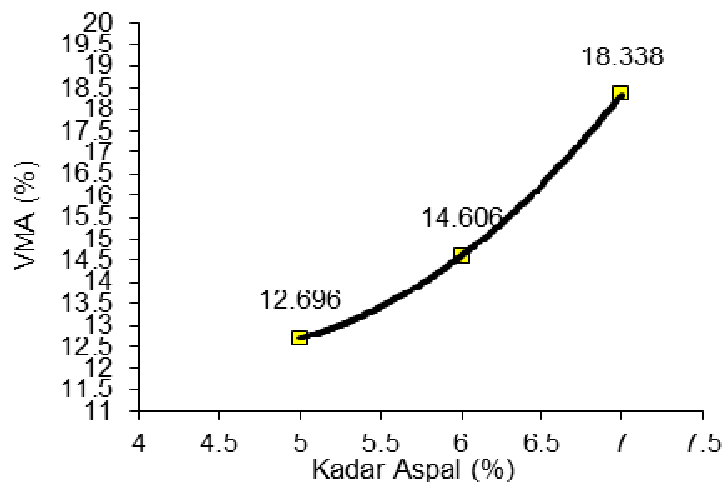

Gambar 7. Rongga Dalam Agregat (VMA)

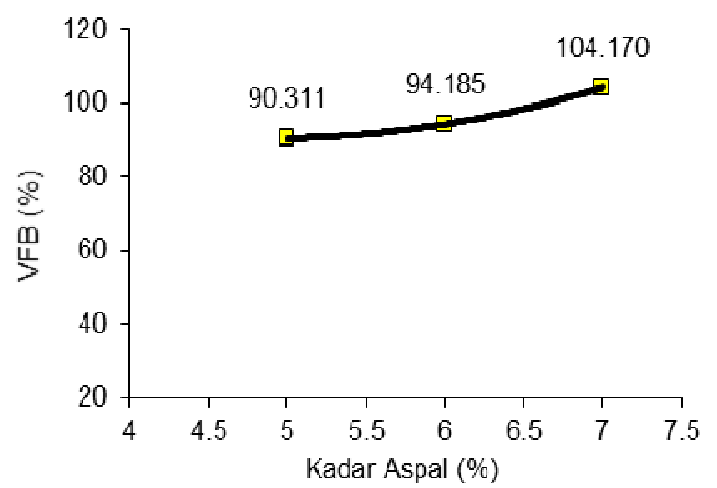

Gambar 8. Rongga Terisi Aspal (VFB)

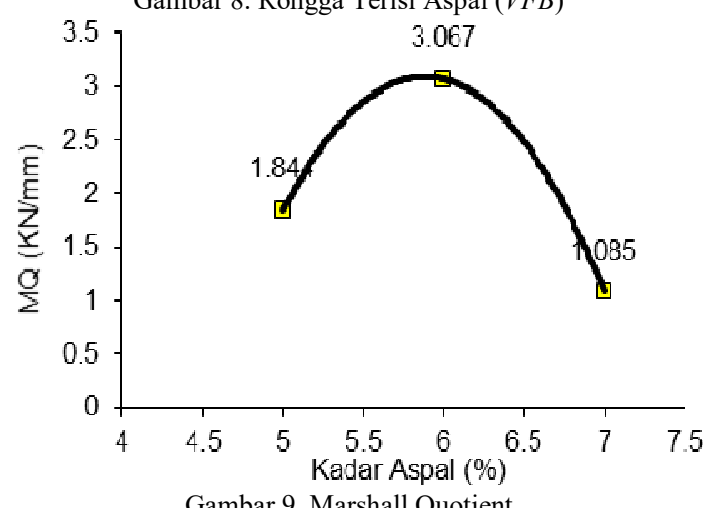

Kadar Aspal Optimum ejurnal.poliban.ac.id

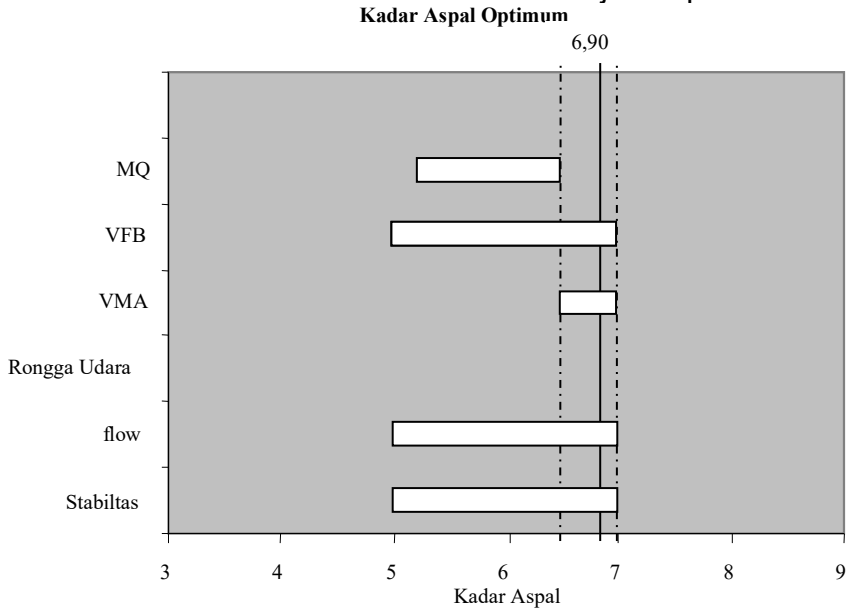

Gambar 10. Hasil Marshall Campuran HRS-WC (Agregat Awang Bangkal)

Berdasarkan hasil percobaan Marshall yang dilakukan (Gambar 10) didapat bahwa kadar aspal optimum berkisar antara 6,5\%-7,0\%. Dalam penelitian ini didapatkan kadar aspal optimum campuran HRS-WC (Agregat Awang Bangkal) sebesar 6,90\% dengan nilai stabilitas sebesar $800 \mathrm{~kg}$

\section{B. HRS-WC Agregat Awang Bangkal dan Katunun Pelaihari}

Berikut adalah hasil pengujian Marshall dengan variasi kadar aspal 5\%-7\% untuk HRS-WC (Agregat gabungan Awang Bangkal dan Katunun Pelaihari).

Tabel XI

Hasil Pengujian Marshall pada Benda Uji dengan Variasi Kadar Aspal 5-7\% untuk HRS-WC Agregat Campuran

\begin{tabular}{|c|c|c|c|c|c|c|c|}
\hline $\begin{array}{c}\text { Kadar } \\
\text { aspal } \\
(\%)\end{array}$ & $\begin{array}{c}\text { Stabilitas } \\
(\mathrm{kg})\end{array}$ & $\begin{array}{c}\text { Flow } \\
(\mathrm{mm})\end{array}$ & $\begin{array}{c}\text { Berat } \\
\text { kering } \\
(\mathrm{gr})\end{array}$ & $\begin{array}{c}\text { Berat } \\
\text { dalam air } \\
(\mathrm{gr})\end{array}$ & $\begin{array}{c}\text { Berat } \\
\text { jenuh } \\
(\mathrm{gr})\end{array}$ & $\begin{array}{c}\text { Tinggi rata- } \\
\text { rata benda } \\
\text { uji (cm) }\end{array}$ & $\begin{array}{c}\text { Koreksi } \\
\text { tinggi }\end{array}$ \\
\hline 5 & 85 & 490 & 1179,8 & 690,3 & 1185,1 & 6,17 & 1,04 \\
5 & 80 & 450 & 1170,2 & 680,3 & 1176,3 & 6,17 & 1,04 \\
5 & 64 & 480 & 1191,3 & 695,2 & 1196,6 & 6,27 & 1,02 \\
5 & 43 & 980 & 1227,7 & 699,7 & 1228,8 & 6,57 & 0,93 \\
\hline 6 & 76 & 460 & 1184,1 & 691,6 & 1186,6 & 6,23 & 1,02 \\
6 & 75 & 500 & 1174,4 & 687,9 & 1178,0 & 6,13 & 1,04 \\
6 & 71 & 500 & 1170,9 & 686,7 & 1174,2 & 6,13 & 1,04 \\
6 & 65 & 410 & 1170,5 & 682,0 & 1173,9 & 6,13 & 1,04 \\
\hline 7 & 60 & 380 & 1164,7 & 683,5 & 1168,1 & 6,10 & 1,04 \\
7 & 62 & 405 & 1169,4 & 681,7 & 1172,5 & 6,17 & 1,04 \\
7 & 57 & 510 & 1185,6 & 690,2 & 1187,0 & 6,20 & 1,04 \\
7 & 57 & 910 & 1176,9 & 686,9 & 1177,7 & 6,10 & 1,04 \\
\hline
\end{tabular}

Analisa Pengujian Marshall Pada Campuran HRS-WC (Agregat Gabungan Awang Bangkal dan Katunun Pelaihari)

\begin{tabular}{|c|c|c|c|c|c|c|}
\hline $\begin{array}{c}\text { Kadar } \\
\text { Aspal } \\
(\%)\end{array}$ & $\begin{array}{c}\text { Stabilitas } \\
\text { Terkoreksi } \\
(\mathrm{kg})\end{array}$ & $\begin{array}{c}\text { Flow } \\
(\mathrm{mm})\end{array}$ & $\begin{array}{c}\text { VIM } \\
(\%)\end{array}$ & $\begin{array}{c}\text { VMA } \\
(\%)\end{array}$ & $\begin{array}{c}\text { VFB } \\
(\%)\end{array}$ & $\begin{array}{c}\text { Marshall } \\
\text { Quotient } \\
(\mathrm{kg} / \mathrm{mm})\end{array}$ \\
\hline 5 & 1013,064 & 4,90 & $-1,640$ & 9,607 & 123,230 & 2,027 \\
5 & 953,472 & 4,50 & $-0,569$ & 10,560 & 110,934 & 2,077 \\
5 & 748,109 & 4,80 & $-1,280$ & 9,928 & 118,831 & 1,528 \\
5 & 458,285 & 9,80 & 1,090 & 12,035 & 95,728 & 0,458 \\
\hline 6 & 888,379 & 4,60 & $-3,271$ & 10,269 & 140,270 & 1,893 \\
6 & 893,880 & 5,00 & $-3,449$ & 10,114 & 142,662 & 1,753 \\
6 & 846,206 & 5,00 & $-3,691$ & 9,904 & 146,028 & 1,659 \\
6 & 774,696 & 4,10 & $-2,728$ & 10,741 & 133,407 & 1,852 \\
\hline
\end{tabular}




\begin{tabular}{|l|l|l|l|l|l|l|}
\hline 7 & 715,104 & 3,80 & $-5,067$ & 10,804 & 157,960 & 1,845 \\
7 & 738,941 & 4,05 & $-4,159$ & 11,576 & 146,159 & 1,789 \\
7 & 679,349 & 5,10 & $-4,326$ & 11,433 & 148,215 & 1,306 \\
7 & 679,349 & 9,10 & $-4,827$ & 11,008 & 154,674 & 0,732 \\
\hline
\end{tabular}

Hasil rata-rata uji Marshall campuran HRS-WC (Agregat gabungan Awang Bangkal dan Katunun Pelaihari) dari masing-masing 4 benda uji dengan kadar aspal 5-7\% dapat disimpulkan pada Gambar 11 sampai Gambar 17 berikut.

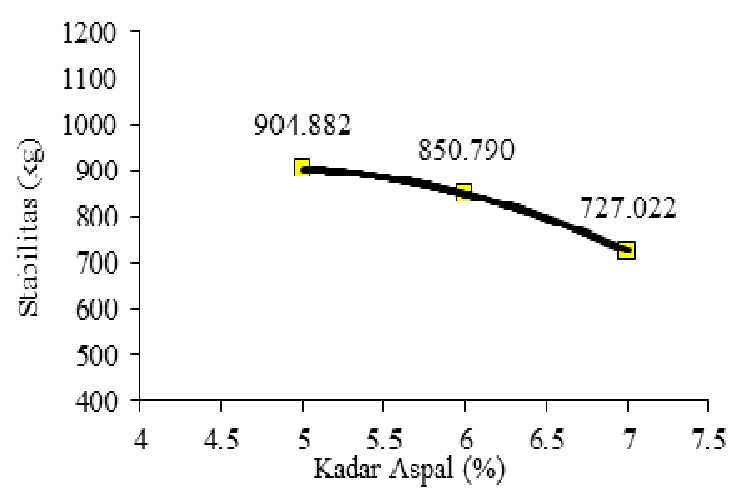

Gambar 11. Stabilitas

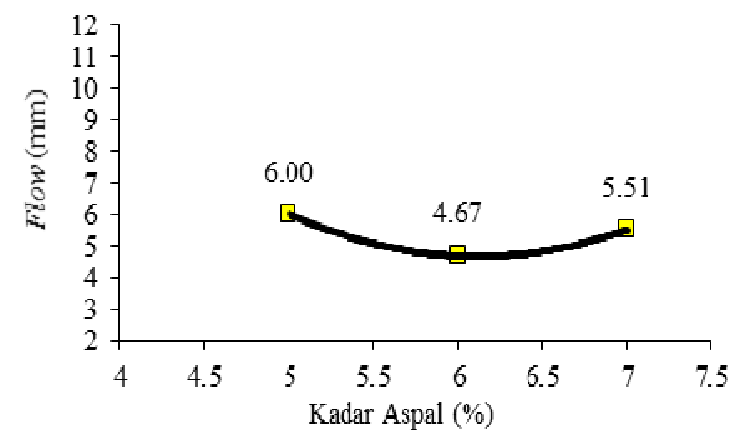

Gambar 12. Pelelehan (Flow)
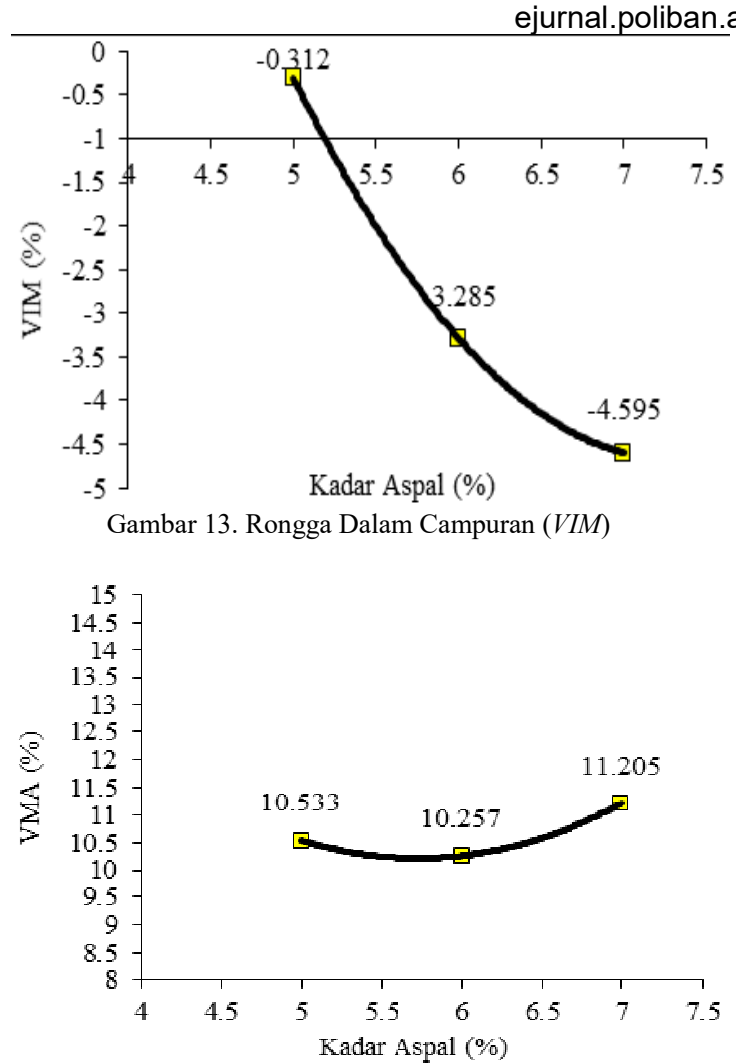

Gambar 14. Rongga Dalam Agregat (VMA)

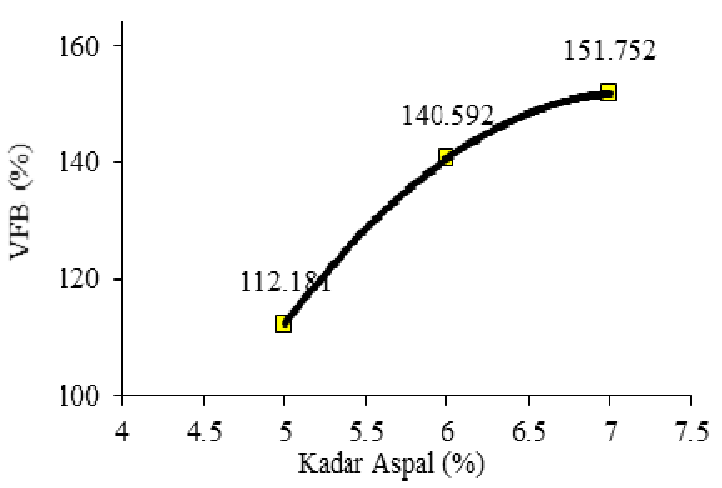

Gambar 15. Rongga Terisi Aspal (VFB)

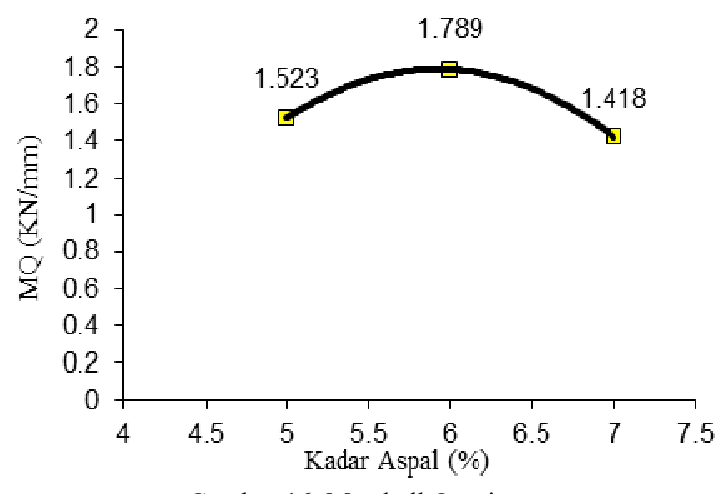

Gambar 16. Marshall Quotient 
ejurnal.poliban.ac.id

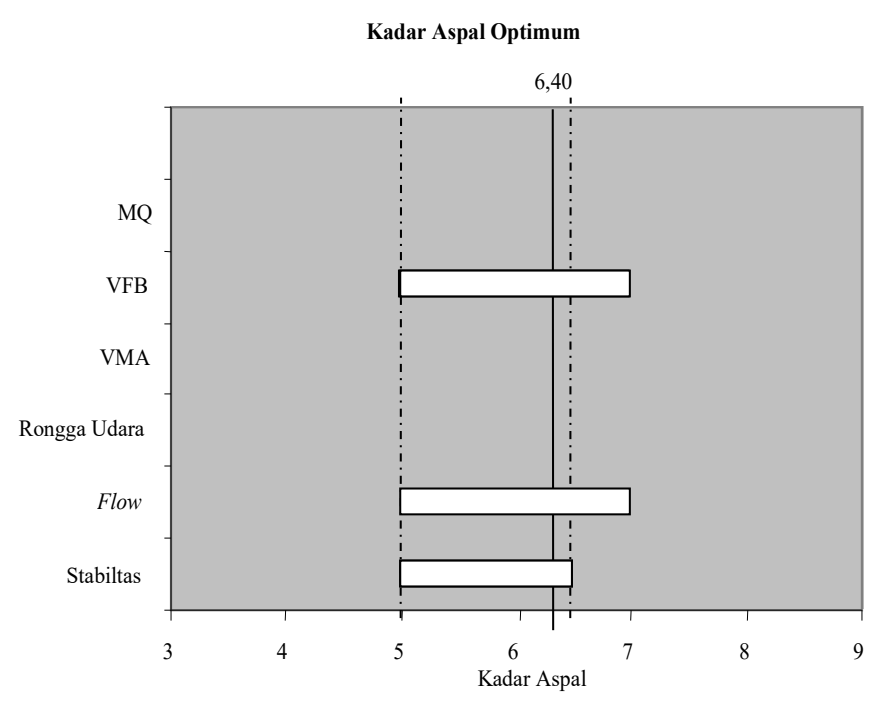

Gambar 17. Hasil Marshall Campuran HRS-WC (Agregat Gabungan Awang Bangkal dan Katunun Pelaihari)

Berdasarkan hasil percobaan Marshall yang dilakukan (Gambar 17) diperoleh kadar aspal optimum antara 5,0\%6,5\%. Dalam penelitian ini didapatkan kadar aspal optimum campuran HRS-WC (Agregat gabungan Awang Bangkal dan Katunun Pelaihari) sebesar $6,40 \%$ dengan nilai stabilitas sebesar $800 \mathrm{~kg}$.

\section{HRS-Base Agregat Awang Bangkal}

Berikut adalah hasil pengujian Marshall dengan variasi kadar aspal 5\%-7\% untuk HRS-Base (Agregat Awang Bangkal).

Tabel XIII

Hasil Pengujian Marshall pada Benda Uji dengan Variasi Kadar Aspal 5-7\% untuk HRS-Base

\begin{tabular}{|c|c|c|c|c|c|c|c|}
\hline $\begin{array}{c}\text { Kadar } \\
\text { aspal } \\
(\%)\end{array}$ & $\begin{array}{c}\text { Stabilitas } \\
(\mathrm{kg})\end{array}$ & $\begin{array}{c}\text { Flow } \\
(\mathrm{mm})\end{array}$ & $\begin{array}{c}\text { Berat } \\
\text { kering } \\
(\mathrm{gr})\end{array}$ & $\begin{array}{c}\text { Berat } \\
\text { dalam air } \\
(\mathrm{gr})\end{array}$ & $\begin{array}{c}\text { Berat } \\
\text { jenuh } \\
(\mathrm{gr})\end{array}$ & $\begin{array}{c}\text { Tinggi } \\
\text { rata-rata } \\
\text { benda uji } \\
(\mathrm{cm})\end{array}$ & $\begin{array}{c}\text { Koreksi } \\
\text { tinggi }\end{array}$ \\
\hline 5 & 65 & 550 & 1176 & 677,3 & 1182 & 6,27 & 1,02 \\
5 & 74 & 510 & 1176 & 680,1 & 1184 & 6,23 & 1,02 \\
5 & 40 & 580 & 1188 & 685,3 & 1197 & 6,40 & 0,96 \\
5 & 54 & 580 & 1181 & 677,6 & 1191 & 6,47 & 0,96 \\
\hline 6 & 56 & 520 & 1166 & 669,1 & 1171 & 6,20 & 1,04 \\
6 & 63 & 660 & 1174 & 672,5 & 1180 & 6,30 & 1,09 \\
6 & 80 & 410 & 1166 & 669,9 & 1170 & 6,23 & 1,02 \\
6 & 64 & 560 & 1164 & 667,7 & 1170 & 6,17 & 1,04 \\
\hline 7 & 56 & 940 & 1178 & 665,9 & 1181 & 6,43 & 0,96 \\
7 & 55 & 1010 & 1176 & 663,7 & 1177 & 6,37 & 1,00 \\
7 & 46 & 840 & 1182 & 670,1 & 1186 & 6,43 & 0,96 \\
7 & 52 & 908 & 1177 & 668,1 & 1179 & 6,37 & 1,00 \\
\hline
\end{tabular}

Tabel XIV

Analisa Pengujian Marshall pada Campuran HRS-Base (Agregat Awang Bangkal)

\begin{tabular}{|c|c|c|c|c|c|c|}
\hline $\begin{array}{c}\text { Kadar } \\
\text { Aspal } \\
(\%)\end{array}$ & $\begin{array}{c}\text { Stabilitas } \\
\text { Terkoreksi } \\
(\mathrm{kg})\end{array}$ & $\begin{array}{c}\text { Flow } \\
(\mathrm{mm})\end{array}$ & $\begin{array}{c}\text { VIM } \\
(\%)\end{array}$ & $\begin{array}{c}\text { VMA } \\
(\%)\end{array}$ & $\begin{array}{c}\text { VFB } \\
(\%)\end{array}$ & $\begin{array}{c}\text { Marshall } \\
\text { Quotient } \\
(\mathrm{kg} / \mathrm{mm})\end{array}$ \\
\hline
\end{tabular}

\begin{tabular}{|c|c|c|c|c|c|c|}
\hline \multicolumn{7}{|c|}{.poliban.ac.ı } \\
\hline 5 & 159,198 & 5,50 & 0,231 & 11,222 & 103,099 & 1,354 \\
\hline 5 & 865,001 & 5,10 & 0,072 & 11,081 & 104,576 & 1,663 \\
\hline 5 & 440,064 & 5,80 & 0,591 & 11,543 & 99,870 & 0,744 \\
\hline 5 & 594,086 & 5,80 & 1,504 & 12,355 & 92,446 & 1,004 \\
\hline $\begin{array}{c}\text { Kadar } \\
\text { Aspal } \\
(\%)\end{array}$ & $\begin{array}{l}\text { Stabilitas } \\
\text { Terkoreksi } \\
\quad(\mathrm{kg})\end{array}$ & $\begin{array}{l}\text { Flow } \\
(\mathrm{mm})\end{array}$ & $\begin{array}{l}\text { VIM } \\
(\%)\end{array}$ & $\begin{array}{c}\text { VMA } \\
(\%)\end{array}$ & $\begin{array}{l}\text { VFB } \\
(\%)\end{array}$ & $\begin{array}{l}\text { Marshall } \\
\text { Quotient } \\
(\mathrm{kg} / \mathrm{mm})\end{array}$ \\
\hline 6 & 667,430 & 5,20 & $-0,733$ & 12,417 & 112,660 & 1,258 \\
\hline 6 & 786,958 & 6,60 & $-0,305$ & 12,789 & 108,917 & 1,169 \\
\hline 6 & 935,136 & 4,10 & $-1,095$ & 12,102 & 116,011 & 2,236 \\
\hline 6 & 762,778 & 5,60 & $-0,480$ & 12,637 & 110,422 & 1,335 \\
\hline 7 & 616,090 & 9,40 & $-0,402$ & 14,701 & 110,465 & 0,643 \\
\hline 7 & 630,300 & 10,10 & $-0,583$ & 14,547 & 111,835 & 0,612 \\
\hline 7 & 506,074 & 8,40 & $-0,586$ & 14,544 & 111,863 & 0,591 \\
\hline 7 & 595,920 & 9,08 & $-1,141$ & 14,072 & 116,247 & 0,643 \\
\hline
\end{tabular}

Hasil Marshall campuran HRS-Base (Agregat Awang Bangkal) dapat dilihat pada Gambar 18-24 berikut.
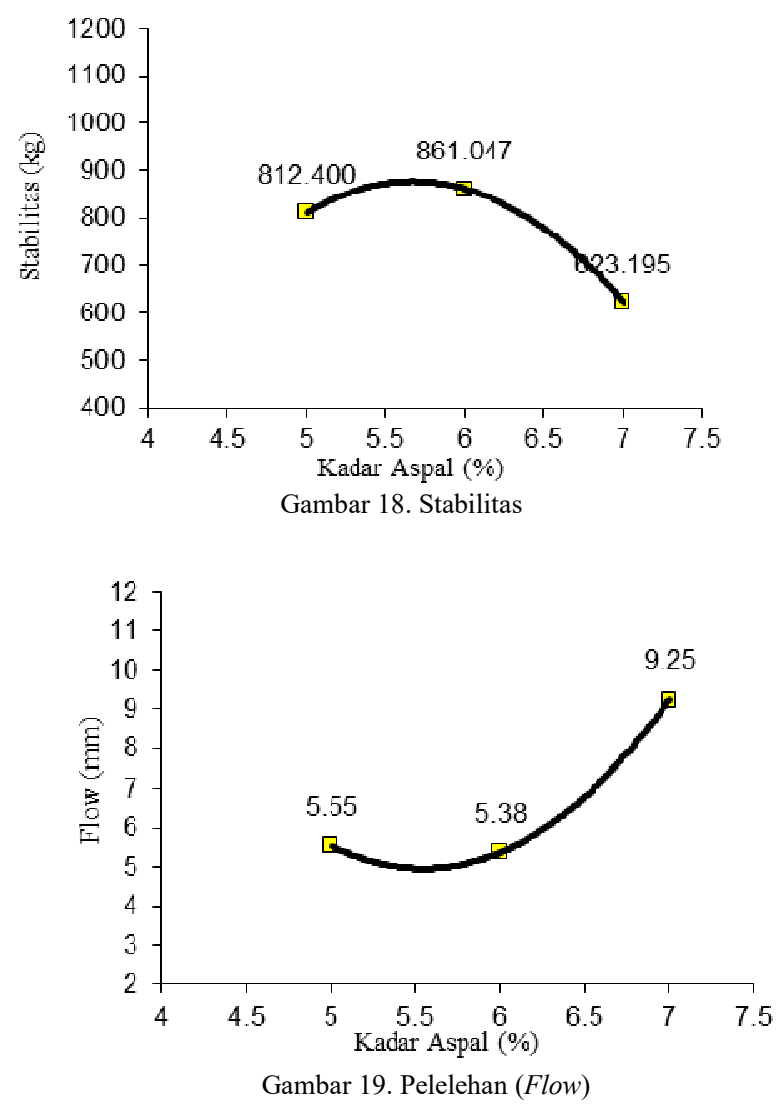


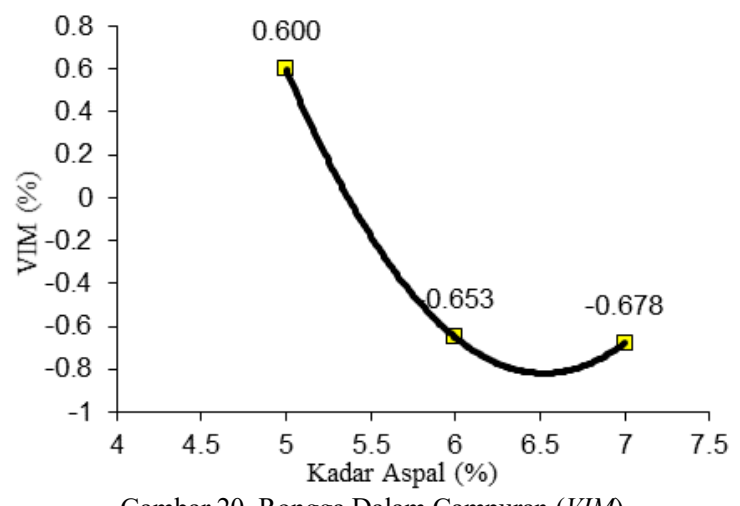

Gambar 20. Rongga Dalam Campuran (VIM)

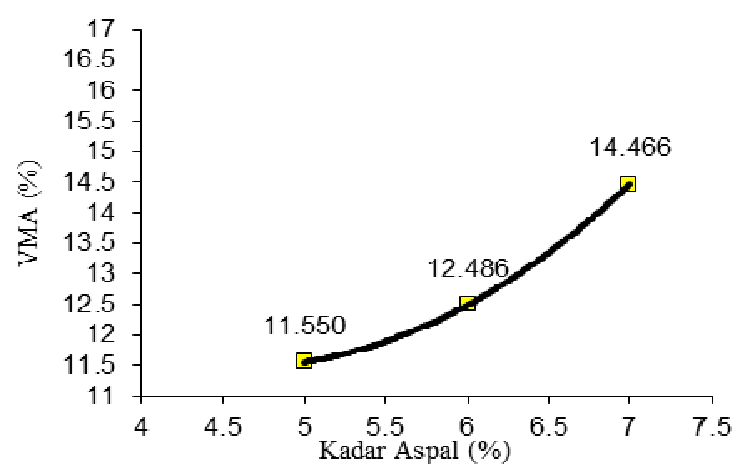

Gambar 21. Rongga Dalam Agregat (VMA)

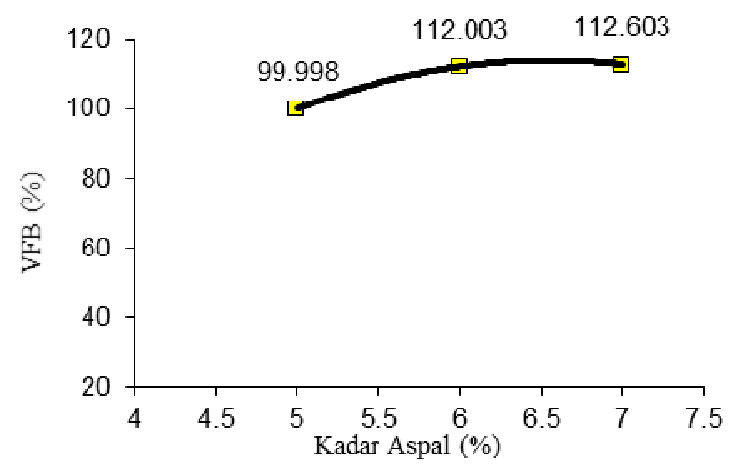

Gambar 22. Rongga Terisi Aspal $(V F B)$

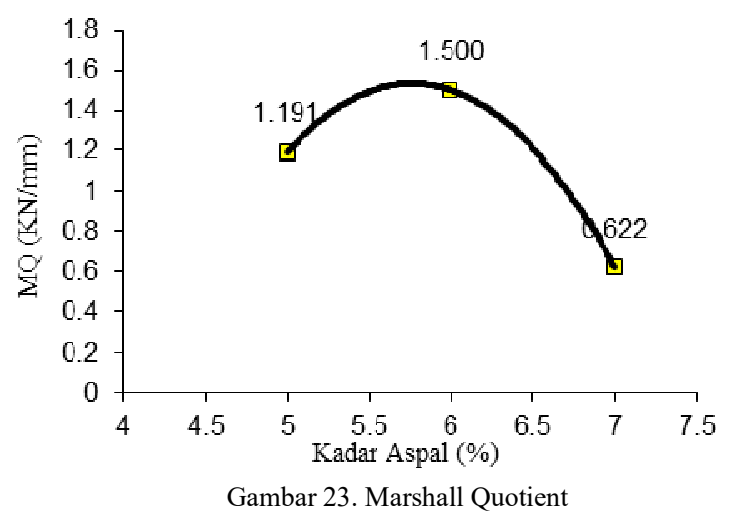

Kadar Aspal Optimum

ejurnal.poliban.ac.id

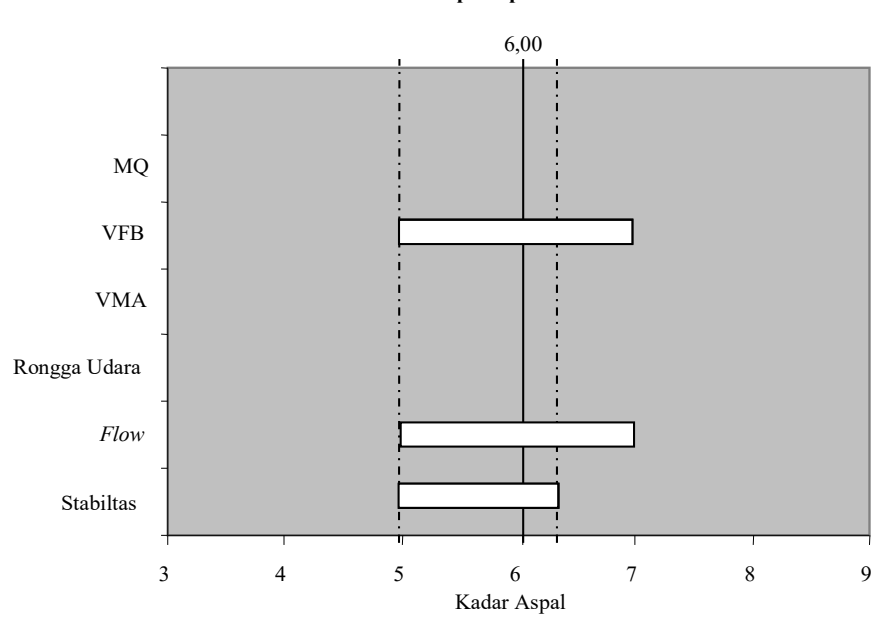

Gambar 24 Hasil Marshall Campuran HRS-Base (Agregat Awang Bangkal)

Berdasarkan hasil percobaan Marshall yang dilakukan (Gambar 24) diperoleh kadar aspal optimum antara 5,0\%6,25\%. Dalam penelitian ini didapatkan kadar aspal optimum campuran HRS-Base (Agregat Awang Bangkal) sebesar $6,00 \%$ dengan nilai stabilitas sebesar $860 \mathrm{~kg}$.

\section{HRS-Base Agregat Awang Bangkal dan Katunun Pelaihari}

Hasil pengujian Marshall dengan variasi kadar aspal 5\%-7\% untuk HRS-Base (Agregat gabungan Awang Bangkal dan Katunun Pelaihari) dapat dilihat pada tabel berikut.

Tabel XV

Hasil Pengujian Marshall pada Benda Uji dengan Variasi Kadar Aspal 5-7\% untuk HRS-Base Agregat Gabungan Awang Bangkal dan Katunun Pelaihari

\begin{tabular}{|c|c|c|c|c|c|c|c|}
\hline $\begin{array}{c}\text { Kadar } \\
\text { aspal } \\
(\%)\end{array}$ & $\begin{array}{c}\text { Stabilitas } \\
(\mathrm{kg})\end{array}$ & $\begin{array}{c}\text { Flow } \\
(\mathrm{mm})\end{array}$ & $\begin{array}{c}\text { Berat } \\
\text { kering } \\
(\mathrm{gr})\end{array}$ & $\begin{array}{c}\text { Berat } \\
\text { dalam air } \\
(\mathrm{gr})\end{array}$ & $\begin{array}{c}\text { Berat } \\
\text { jenuh } \\
(\mathrm{gr})\end{array}$ & $\begin{array}{c}\text { Tinggi } \\
\text { rata-rata } \\
\text { benda uji } \\
(\mathrm{cm})\end{array}$ & $\begin{array}{c}\text { Koreksi } \\
\text { tinggi }\end{array}$ \\
\hline 5 & 49 & 410 & 1159,9 & 663,2 & 1170,5 & 6,40 & 0,96 \\
5 & 72 & 460 & 1168,3 & 680,2 & 1173,6 & 6,17 & 1,04 \\
5 & 60 & 450 & 1162,9 & 671,6 & 1172,9 & 6,30 & 1,09 \\
5 & 40 & 440 & 1164,7 & 676,1 & 1174,5 & 6,33 & 1,00 \\
\hline 6 & 63 & 510 & 1168,9 & 684,4 & 1171,3 & 6,17 & 1,04 \\
6 & 78 & 505 & 1167,9 & 684,0 & 1172,5 & 6,20 & 1,04 \\
6 & 48 & 540 & 1164,1 & 675,5 & 1171,2 & 6,23 & 1,02 \\
6 & 61 & 680 & 1180,1 & 691,7 & 1182,2 & 6,17 & 1,04 \\
\hline 7 & 51 & 540 & 1156,3 & 664,3 & 1160,9 & 6,20 & 1,04 \\
7 & 64 & 707 & 1170,5 & 686,9 & 1172,5 & 6,07 & 1,09 \\
7 & 49 & 880 & 1164,4 & 668,2 & 1166,1 & 6,23 & 1,02 \\
7 & 55 & 690 & 1172,3 & 670,9 & 1174,4 & 6,30 & 1,09 \\
\hline
\end{tabular}

Tabel XVI

Analisa Pengujian Marshall pada Campuran HRS-Base (Agregat gabungan Awang Bangkal dan Katunun Pelaihari)

\begin{tabular}{|c|c|c|c|c|c|c|}
\hline $\begin{array}{c}\text { Kadar } \\
\text { Aspal } \\
(\%)\end{array}$ & $\begin{array}{c}\text { Stabilitas } \\
\text { Terkoreksi } \\
(\mathrm{kg})\end{array}$ & $\begin{array}{c}\text { Flow } \\
(\mathrm{mm})\end{array}$ & $\begin{array}{c}\text { VIM } \\
(\%)\end{array}$ & $\begin{array}{c}\text { VMA } \\
(\%)\end{array}$ & $\begin{array}{c}\text { VFB } \\
(\%)\end{array}$ & $\begin{array}{c}\text { Marshall } \\
\text { Quotient } \\
(\mathrm{kg} / \mathrm{mm})\end{array}$ \\
\hline 5 & 539,078 & 4,10 & 2,101 & 12,886 & 88,101 & 1,289 \\
5 & 858,125 & 4,60 & $-1,386$ & 9,783 & 120,176 & 1,829 \\
5 & 749,484 & 4,50 & 0,673 & 11,615 & 99,165 & 1,633 \\
5 & 458,400 & 4,40 & $-0,060$ & 10,963 & 105,836 & 1,021 \\
\hline
\end{tabular}




\begin{tabular}{|l|c|c|c|c|c|c|}
\hline 6 & 750,859 & 5,10 & $-4,094$ & 9,495 & 152,257 & 1,443 \\
6 & 929,635 & 5,05 & $-3,665$ & 9,868 & 145,888 & 1,805 \\
6 & 561,082 & 5,40 & $-1,826$ & 11,466 & 123,328 & 1,019 \\
6 & 727,022 & 6,80 & $-4,320$ & 9,298 & 155,814 & 1,048 \\
\hline 7 & 607,838 & 5,40 & $-2,224$ & 13,153 & 125,706 & 1,104 \\
7 & 799,450 & 7,07 & $-5,823$ & 10,095 & 169,552 & 1,109 \\
7 & 572,771 & 8,80 & $-2,671$ & 12,773 & 130,012 & 0,638 \\
7 & 687,027 & 6,90 & $-2,218$ & 13,158 & 125,652 & 0,976 \\
\hline
\end{tabular}

Hasil Marshall campuran HRS-Base (Agregat gabungan Awang Bangkal dan Katunun Pelaihari) dapat dilihat pada Gambar 25-31 berikut.

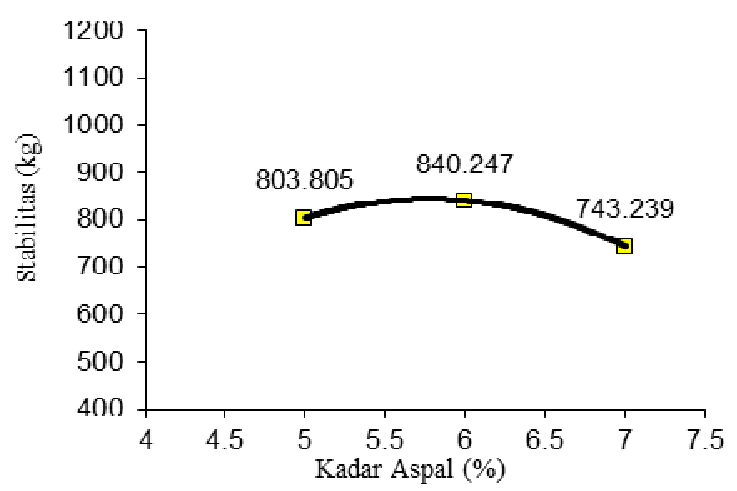

Gambar 25. Stabilitas

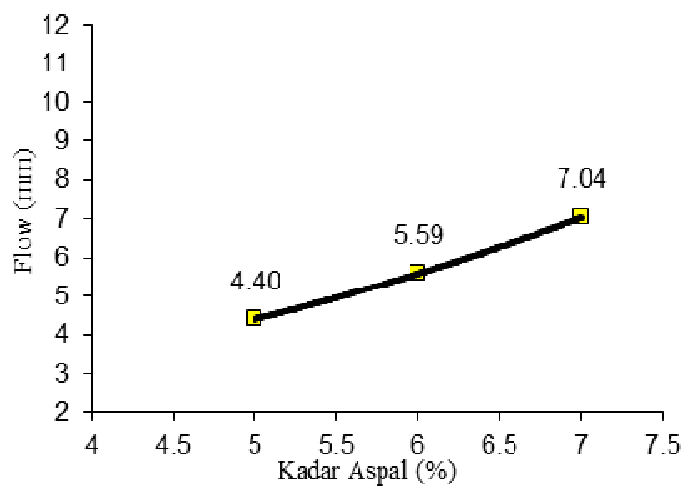

Gambar 26. Pelelehan (Flow)

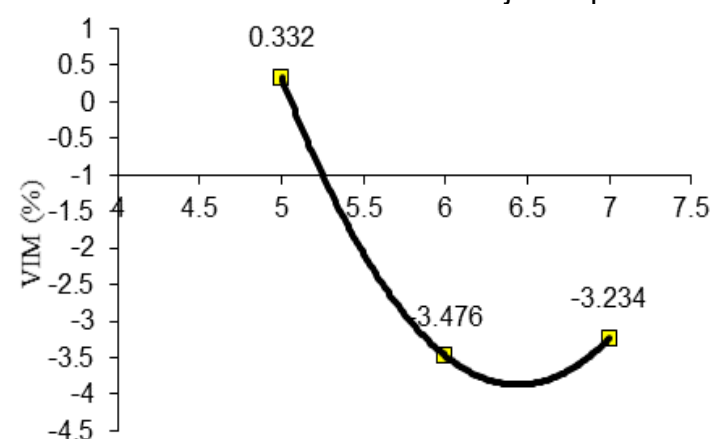

Kadar Aspal (\%)

Gambar 27. Rongga Dalam Campuran (VIM)

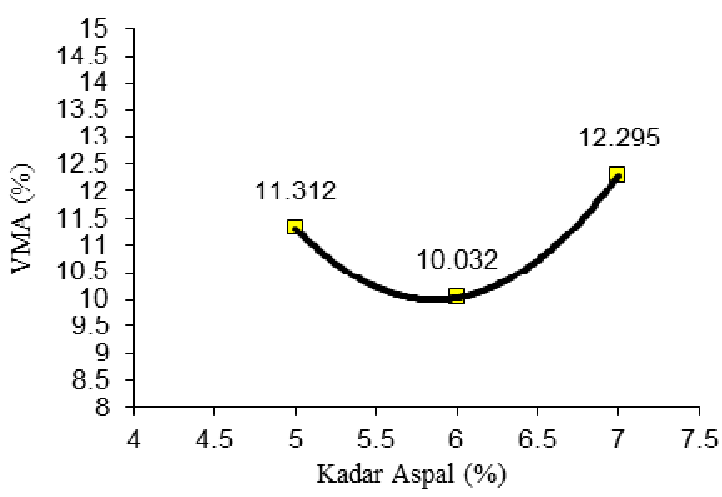

Gambar 28. Rongga Dalam Agregat $(V M A)$

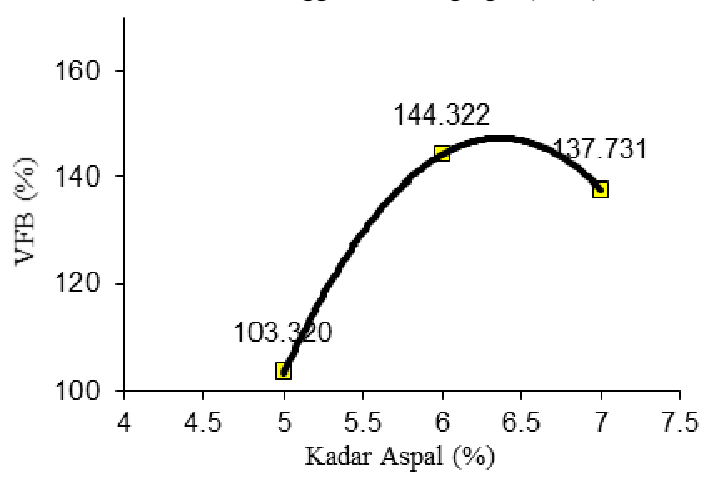

Gambar 29. Rongga Terisi Aspal (VFB)

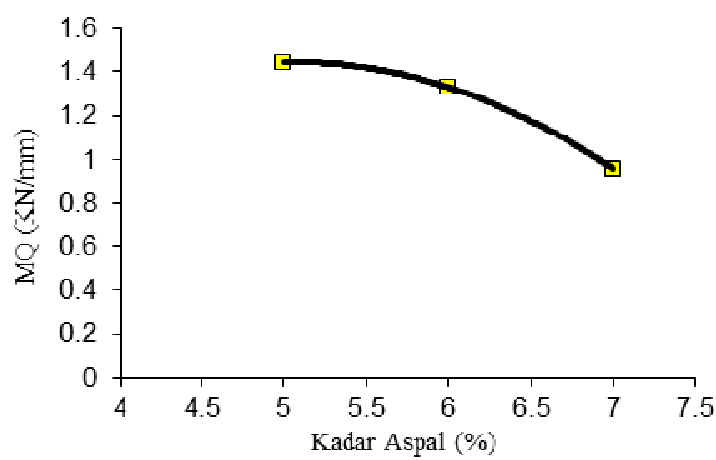


Gambar 30. Marshall Quotient

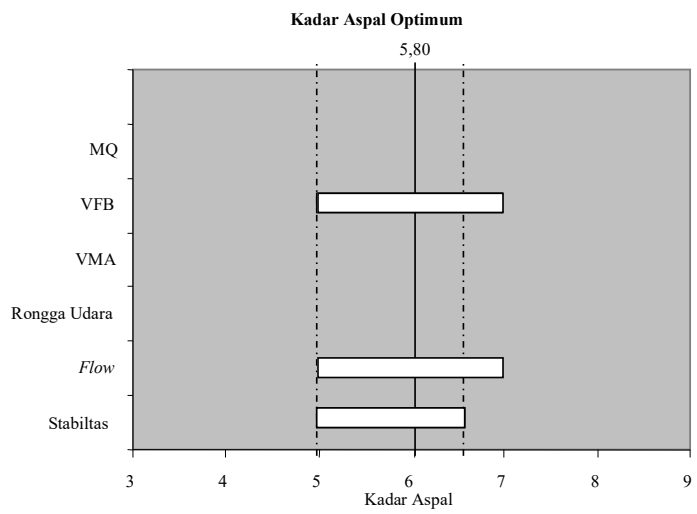

Gambar 31. Hasil Marshall Campuran HRS-Base (Agregat Gabungan Awang Bangkal dan Katunun Pelaihari)

Berdasarkan hasil percobaan Marshall yang dilakukan (Gambar 5) didapat bahwa kadar aspal optimum berkisar antara 5,0\%-6,5\%. Dalam penelitian ini didapatkan kadar aspal optimum campuran HRS-Base (Agregat gabungan Awang Bangkal dan Katunun Pelaihari) sebesar 5,80\% dengan nilai stabilitas sebesar $850 \mathrm{~kg}$.

Dokumentasi pelaksanaan pengujian Marshall dapat dilihat pada Gambar 32 sampai Gambar 34 berikut.

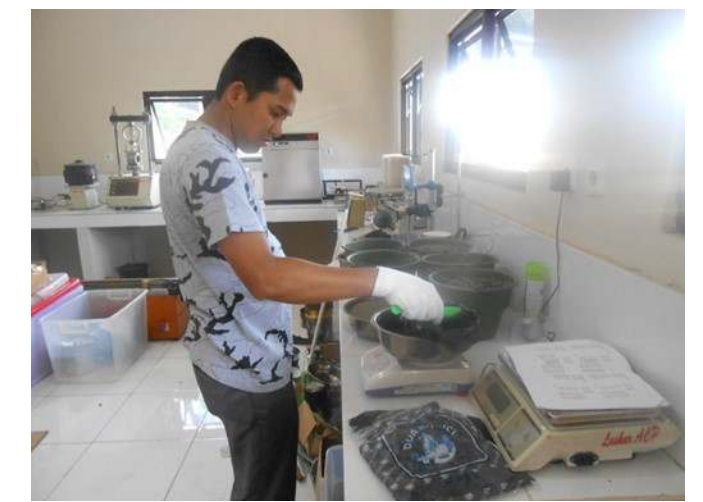

Gambar 32. Penimbangan Agregat untuk Pembuatan Benda Uji

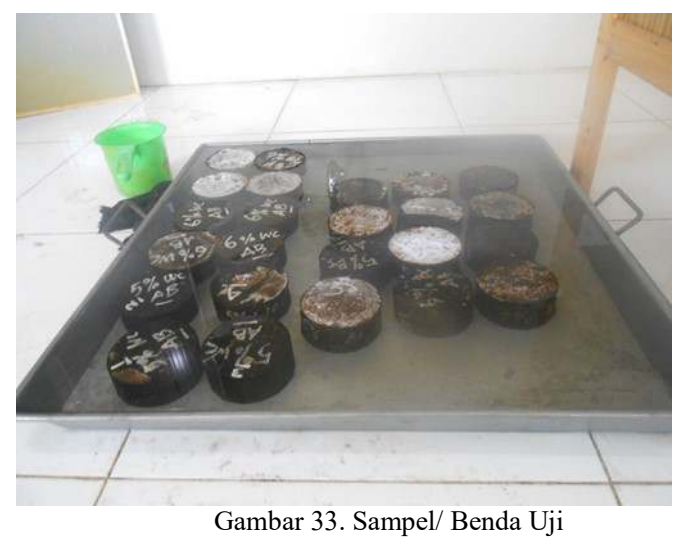

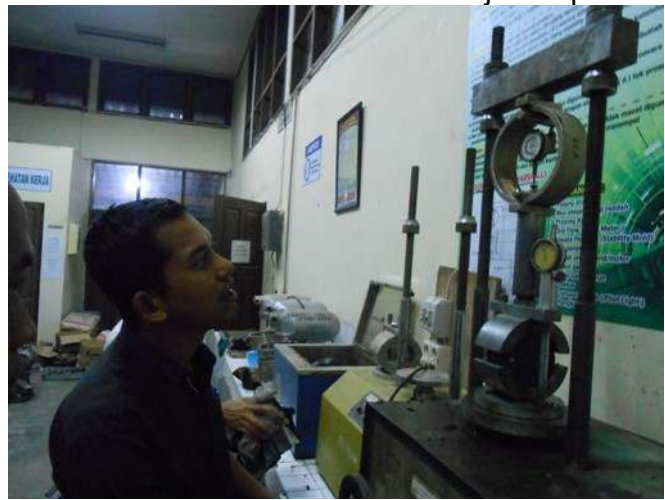

Gambar 34. Test Marshall untuk Menentukan Nilai Stabilitas dan Flow

\section{E. Pembahasan Pengaruh Agregat Gabungan}

1) Agregat Kasar: Berdasarkan pengujian keausan/abrasi yang dilakukan pada agregat kasar Awang Bangkal didapatkan nilai keausan sebesar $44,13 \%$ yang berarti tidak memenuhi persyaratan yang ada pada spesifikasi yaitu $<40 \%$. Sedangkan agregat kasar Katunun Pelaihari didapatkan nilai keausan sebesar $24,12 \%$ yang berarti telah memenuhi persyaratan yang ada pada spesifikasi yaitu $<40 \%$. Hal ini menunjukkan bahwa agregat kasar berupa batu pecah Awang Bangkal tidak dapat digunakan untuk campuran aspal Lataston Lapis Aus (HRS-WC) dan Lataston Lapis Pondasi (HRS-Base).

2) Agregat Halus: Hasil pengujian agregat halus berupa pasir Barito menunjukkan nilai penyerapan didapatkan sebesar $0,685 \%$ yang berarti telah memenuhi persyaratan yang ada pada spesifikasi yaitu $<3 \%$, Hal ini menunjukkan bahwa pasir Barito dapat digunakan untuk campuran aspal Lataston Lapis Aus (HRS-WC) dan Lataston Lapis Pondasi (HRS-Base).

3) Filler: Filler yang digunakan adalah abu batu dan semen Tiga Roda yang lolos saringan No. 200 tidak menggumpal dan bersifat non plastis. Dari pengujian filler abu batu menunjukkan tingkat penyerapan sebesar $1,112 \%$ yang berarti telah memenuhi persyaratan pada spesifikasi yaitu $<3 \%$.

4) Aspal: Dari pengujian aspal didapatkan nilai penetrasi sebesar 65,3 mm yang berarti telah memenuhi spesifikasi (6079). Begitu juga dengan berat jenis aspal sebesar $1,06 \mathrm{gr} / \mathrm{cc}$ telah memenuhi spesifikasi yaitu lebih besar dari $1,00 \mathrm{gr} / \mathrm{cm}^{3}$. Untuk titik lembek terjadi pada suhu $48,75^{\circ} \mathrm{C}$ telah memenuhi spesifikasi yaitu $48^{\circ} \mathrm{C}-58^{\circ} \mathrm{C}$, sehingga aspal dengan penetrasi 60/70 dapat digunakan dalam campuran HRS-WC dan HRSBase.

5) Campuran Aspal: Pada campuran HRS-WC (Agregat Awang Bangkal) didapatkan nilai kadar aspal optimum sebesar 6,90\% dengan nilai stabilitas sebesar $800 \mathrm{~kg}$. Sedangkan pada campuran HRS-WC (Agregat gabungan Awang Bangkal dan Katunun Pelaihari) didapatkan nilai kadar aspal optimum sebesar 6,40\% dengan nilai stabilitas sebesar $800 \mathrm{~kg}$. Pada kondisi ini terjadi pengurangan 
pemakaian kadar aspal optimum sebesar 6,90 \% dikurang $6,40 \%$ sama dengan $0,5 \%$,akibat pengaruh agregat gabungan. Pada campuran HRS-Base (Agregat Awang Bangkal) didapatkan nilai kadar aspal optimum sebesar 6,00\% dengan nilai stabilitas sebesar $860 \mathrm{~kg}$. Sedangkan pada campuran HRS-Base (Agregat gabungan Awang Bangkal dan Katunun Pelaihari) didapatkan nilai kadar aspal optimum sebesar $5,80 \%$ dengan nilai stabilitas sebesar $850 \mathrm{~kg}$. Pada kondisi ini terjadi pengurangan pemakaian kadar aspal optimum sebesar $6,00 \%$ dikurang $5,8 \%$ sama dengan $0,2 \%$, akibat pengaruh agregat gabungan.

\section{KESIMPULAN}

Dari hasil penelitian yang telah dilakukan dapat ditarik kesimpulan bahwa pengaruh agregat gabungan Awang Bangkal dan Katunun Pelaihari pada campuran Lataston Lapis Aus (HRS-WC) dapat mengurangi pemakaian kadar aspal optimum sebesar $0,5 \%$ dengan nilai stabilitas memenuhi spesifikasi yang disyaratkan minimal sebesar $800 \mathrm{~kg}$ sedangkan pada campuran Lataston Lapis Pondasi (HRSBase) dapat mengurangi pemakaian kadar aspal optimum sebesar $0,2 \%$ dengan nilai stabilitas memenuhi spesifikasi yang disyaratkan minimal sebesar $800 \mathrm{~kg}$.

\section{REFERENSI}

2010. Spesifikasi Divisi 6.3 Campuran Beraspal Panas. Direktur Jenderal Bina Marga. Jakarta.

Departemen Pekerjaan Umum Direktorat Jendral Bina Marga. 1983. Petunjuk Pelaksanaan Lapis Perkerasan. Jakarta.

Hendarsin, Shirley. L. 2000. Perencanaan Teknik Jalan Raya. Politeknik Negeri Bandung Jurusan Teknik Sipil. Bandung.

Hifni, M. 1991. Metode Statistika. Fakultas Teknik Universitas Brawijaya. Malang.

Radam F, Iphan. 2008. Bahan Ajar: Rekayasa Lalu Lintas. Universitas Lambung Mangkurat Press. Banjarmasin

Sukirman, S. 1999. Perkerasan Lentur Jalan Raya. Nova. Bandung. 